\title{
Inter-regional migration in Indonesia: a micro approach
}

\author{
Nashrul Wajdi ${ }^{1}$ Clara H. Mulder ${ }^{1}$ - Sri M. Adioetomo ${ }^{2,3}$
}

(C) The Author(s) 2017. This article is an open access publication

\begin{abstract}
We study the extent to which the likelihood of specific types of migration in Indonesia varies by the situation in the labour market and family life course. We distinguish migration types according to origin and destination (Jakarta, other metropolitan areas, and non-metropolitan areas). For migration from Jakarta, we also distinguish migration to other metropolitan areas within commuting distance. As expected, we find that young adults are the most mobile category. As an exception, migration from Jakarta to nearby metro areas was just as likely for ages 30-54 as for ages 23-29. Our findings suggest that migration to Jakarta and other metropolitan areas, in particular, is most likely undertaken for better education or jobs. Married people are more likely than others to leave Jakarta for nearby metropolitan areas.
\end{abstract}

Keywords Migration $\cdot$ Life course $\cdot$ Metropolitan areas $\cdot$ Indonesia

\section{Introduction}

Attention to population growth in many developing countries, including Indonesia, has mainly been focused on fertility in the context of family planning programs and policies aiming at a reduction of fertility. However, along with declining fertility

Nashrul Wajdi

n.wajdi@rug.nl

1 Population Research Centre, Faculty of Spatial Sciences, University of Groningen, Landleven 1, 9747 AD Groningen, The Netherlands

2 Master Program on Economics of Population and Labour, Faculty of Economics and Business, Universitas Indonesia, Depok, Indonesia

3 Demographic Institute, Faculty of Economics and Business, Universitas Indonesia, Depok, Indonesia 
and increasing life expectancy, population distribution is also an important issue (De Jong and Gardner 1981). To date, Indonesia is experiencing an unequal distribution of the population where more than $50 \%$ of the total population live in Java Island (6.8\% of Indonesia's territory). This unequal distribution of the population has been a major concern among policymakers and scientists alike (see for example Alatas 1993; Chotib 1999; Darmawan and Chotib 2007; Firman 1994).

From a macro perspective, the movement of people to Java Island was associated with the attractiveness of metropolitan areas in Java Island (Wajdi et al. 2015). Wajdi et al. (2015) used Long's (1985) framework of population redistribution phases and focused on macro level migration flows rather than the micro-level behaviour of individuals. According to Greenwood (1997), the inclusion of micro factors in macro models of migration is not appropriate. Yet taking the individual characteristics of potential migrants into account is crucial to understanding migration.

Despite the growing number of studies on migrants' characteristics in Indonesia (see for example Ananta et al. 2001; Chotib 1999; Muhidin 2002), research that helps understand how individual characteristics are related to particular types of movement is still lacking. To fill this research gap, this paper aims to explore the relation between individual characteristics and different types of migration. We distinguished types of migration according to origin and destination. First, from Jakarta to other metropolitan areas within commuting distance, to other more distant metropolitan areas and to non-metropolitan areas. Second, from other metropolitan areas to Jakarta, to other metropolitan areas and to non-metropolitan areas. Third, from non-metropolitan areas to Jakarta, to other metropolitan areas and to nonmetropolitan areas. In the remainder of the paper, the term metro stands for metropolitan.

We argue that migration is a mechanism to achieve better education, job opportunities, and/or living environment; and different characteristics of an individual will be associated with different types of migration. Since migration is strongly related to the life course, we use the life course approach to explore the effects of specific life course factors, such as age, education, labour market participation and family formation, on inter-regional migration in Indonesia. The question we address is: to what extent does the likelihood of a certain type of migration vary by situation in the labour market and family life course? To answer this question, we utilise the Indonesian Population Censuses (PC2000 and PC2010) and the Indonesian Intercensal Survey (also known as SUPAS2005). As an analytical strategy, we estimate multinomial logistic regression models for multiple migration outcomes by origin.

\section{Theoretical framework}

Migration represents a form of utility-maximizing behaviour that distinguishes migrants from their counterparts, stayers (Greenwood 1975). It can be considered first and foremost a mechanism to achieve better education, job opportunities and/or living environment. In the macro context-including the economic and political 
context - opportunities will drive migration while constraints will hinder it (Mulder and Hooimeijer 1999). Furthermore, the social and environmental situation to which a person has been exposed shapes that person's life (Elder 1994; Elder et al. 2003). As Stevens (1980) has argued, non-monetary factors, e.g. degree of pollution and quality of life, strongly affect migration from metropolitan areas to non-metropolitan areas. In the case of Indonesia, Jakarta is known for its relatively low air quality, congestion, and high density. A study by Wajdi et al. (2015) showed that Jakarta had larger outflows to than corresponding inflows from Bodetabek (a metro area surrounding Jakarta), indicating a preference for low-density locations over Jakarta.

In terms of the migration-development relationship, some studies (see for example Wajdi et al. 2015; World Bank 2012) have shown that migration is directed towards more developed regions; that is, metropolitan areas in Java. The World Bank (2012) utilised GDP divided by the size of the urban land area to measure the economic density of a region and showed that the metropolitan areas in Java have a high economic density as a further evidence of the gap in economic development.

In addition to opportunities and constraints in the macro context, circumstances embedded at the micro level, i.e. individuals' lives, are important in migration processes (De Groot et al. 2011; Findlay et al. 2015; Mulder and Hooimeijer 1999). Because migration is a result of complex events in individuals' life courses and is a part of these life courses, the life course perspective can provide a useful starting point for the explanation of inter-regional migration in Indonesia. A life course is defined as a sequence of socially defined roles embedded in an individual's daily routine activities starting from birth and ending at death (Elder et al. 2003; Mayer $2004,2009)$. The choices individuals make, and the actions they undertake will affect the construction of their life courses (Elder 1994; Elder et al. 2003). In the individual life course, certain major life events have strong triggering effects on migration. Life events will also result in different situations in individual life courses that have an impact on migration: the individual's resources will enhance migration while restrictions will hinder migration (Mulder and Hooimeijer 1999; see also Kley and Mulder 2010). Furthermore, as Mulder (1993) stated, events and situations in people's life courses not only affect migration in general but also cause different migration types in terms of distance, direction and destination choice. Thus, different types of people, at different life course stages, will respond in different ways to the various types of migration stimuli (Feliciano 2005; Rahman 1991). For example, the importance of education, jobs, and residential environment will differ by life-course stage. The importance of individual characteristics for migration, including age, sex, education, participation in the labour market and marital status, has been documented in the literature (see for example Fischer and Malmberg 2001; Greenwood 1985).

Age is a key variable that is strongly related to migration and widely used as a predictor of and as a proxy for the life course stage. The age-migration dependency, also known as age migration schedule, shows that migrant is relatively young when they leave home for the quest of new places, and at the same time, several events in their lives induce decisions to migrate. Migration propensities then steadily decline with increasing age, although in some contexts it rises again around the age of retirement or ages at which many people are in need of care. This age migration profile reflects the age structure of life course transitions, which, in turn, 
is strongly influenced by the socio-economic context (Bernard et al. 2014, 2016; Clark and Huang 2003; Clark 2013; Fischer and Malmberg 2001; Rogers and Castro 1981; Rogers et al. 2004).

From the work of Warnes (1992) on the relation between life course transitions and migration, it is clear that migration patterns differ for each age and each life course transition. Furthermore, age affects not only the likelihood of moving but also the direction of migration, through different migration motivations (Stockdale and Catney 2014). The decisions of young adults to leave the parental home affects migration patterns. Young adults in need of education and employment mainly move to areas where they can access better education and job opportunities (Boyle et al. 1998; Mulder and Hooimeijer 1999; Stockdale 2002). Wajdi (2010) found that the most mobile group with regard to inter-island migration in Indonesia was aged 23-54 years and that the main reasons for migration for this age group were economic, familyrelated, and education-related. At around 20-30 years, the life course transitions related to migration are union formation, for which migrants tend to prefer short distance moves to low-to-medium cost areas or areas with rental properties, and job change, for which distances tend to be longer and destinations more frequently in metro areas. The distance of migration is even shorter for the age around which the first child of a family is born (generally age 23-30 years, depending on the context), while the preferred destinations are more frequently those more suited to bringing up children. Around 27-55 years when migration is less frequent, there could be long distance migration to metro areas for career promotion, but also short-distance moves to low-cost or medium-cost rental properties associated with divorce and the formation of second unions (Boyle et al. 1998; Warnes 1992).

Nivalainen (2003) found that the somewhat higher propensity of migration around retirement age from urban to rural areas in Finland was not related to income and the location of jobs. For the United States, Whisler et al. (2008) found that retirees were most likely to move from metropolitan areas with high living costs and unfavourable climates to more affordable and comfortable areas. In line with Whisler et al. (2008)'s findings, Stockdale and Catney (2014) found for the case of Northern Ireland that people around retirement age featured in migration from urban centres towards rural destinations. Stockdale and Catney (2014) argued that this socalled counterurbanisation occurs because of the lesser importance among older than younger people of living close to the urban employment centres. With regard to affordable and comfortable areas in the case of Indonesia, the Cost of Living Survey 2012 (Survey Biaya Hidup 2012) by Statistics Indonesia (2013a, b, c) shows that the living costs in certain metro areas were higher compared to other areas. For example, the monthly cost of living in Jakarta in 2012 was 7.5 million rupiahs per month, compared to Bodetabek (the area surrounding Jakarta) with an average monthly cost of living of 5.3 million rupiahs per month.

Life courses are differentiated by gender (Biddle and Yap 2010). One example of a gender difference in life courses is the timing of entering and exiting the labour market (Bernard et al. 2014). The likelihood of migrating would therefore probably differ between women and men. Gender differences in the likelihood of migration could also be approached from the perspective of gender roles. In Indonesia (see for example Ananta et al. 2001) and also in Thailand (De Jong 2000), kin-based and 
domestic roles are traditionally assigned to women. Women are expected to take care of children and elderly in the family while men are more free from these domestic roles and are expected to explore the world (merantau) (Naim 1974: pp. 31, 41, 268, 324). Because of this difference in responsibilities, the likelihood of migration is likely gendered (Ananta et al. 2001; De Jong 2000). In the case of Indonesia, in general, we expect that men have a higher likelihood of migration than women. With regard to migration types, we expect that women are more likely to migrate to more developed areas where the industry sector is dominant. We expect that men are more likely to migrate to less developed areas where agriculture is dominant. These expectations are based on the gender preference in demand for labour in certain areas. For instance, in metro areas with a lot of factories, e.g. Jakarta and Gerbangkertosusila, the demand for female labour is high, while in some areas with a high share of the non-industrial sector the demand for male labour is high.

Education is also known for its strong influence on the likelihood of migration (see for example Basker 2003; Greenwood 1997). Moreover, for those with high educational attainment, distance is less of an obstacle to moving (Kodrzycki 2001). The level of education not only affects the likelihood of migration but also the direction of migration: skilled labour tends to move from less developed areas to more developed areas (Iredale 2001). For the United States, Whisler et al. (2008) showed that college-educated persons have preferences for very specific destinations, that is, young graduates have a strong preference for large metropolitan areas. A study by Stockdale and Catney (2014) for rural-urban migration in Northern Ireland showed that migration from rural areas to urban areas is commonly characterized by young adults moving for tertiary education and/or looking for a job. In general, we expect that those with a higher level of education have a higher likelihood of migrating. Regarding migration type, we expect that highly educated people will be particularly likely to migrate to areas where the education facilities are better than in their current area in order to pursue a better education. For instance, those who live in Jakarta would be more likely to move to a metro area surrounding Jakarta because one of the largest universities in Indonesia (the University of Indonesia) is located in Depok, a metro area within commuting distance from Jakarta.

Regarding participation in the labour market, actual or anticipated changes in employment frequently motivate migration (DaVanzo 1978; De Groot et al. 2011; Stockdale and Catney 2014). Those who are employed are less likely to migrate than those who are unemployed or not in the labour market (Basker 2003). Because more developed areas (metropolitan areas) provide more opportunities compared to less developed areas, and at the same time the requirements are high in such areas, we expect that particularly highly educated people tend to migrate to more developed areas. In the Indonesian context, working in the formal sector is considered better than working in the informal sector. But working (whether in the formal or informal sectors) is considered much better than being unemployed. Those who are working in the formal sector are considered by the community to be more prosperous than those who are working in the informal sector or those who are unemployed. Therefore, those who are not absorbed in the formal sector in Jakarta are expected to be likely to move to areas where they can work (which, for some, could be non-metro areas). 
Union formation and marriage have been found to have a strong effect on migration (Courgeau 1985; Mulder and Wagner 1993). As Mincer (1978) stated, the decision to migrate is usually made at the household level. It is more difficult to move if no agreement is reached concerning the decision to migrate. Therefore, those who are married are expected to be less likely to migrate than those who are single.

With regard to destinations, there is evidence that plans to have a child trigger leaving the city (Kulu 2008). As Kley (2011) argued, an important motive for leaving the city for both families with children and couples anticipating having children is the wish to live in a spacious dwelling or a child-friendly environment. Whisler et al. (2008) found for the United States that families with children prefer low-density areas while those who are young without children are very mobile and move to areas where they can find opportunities for recreation and entertainment as well as educational and job opportunities. Although the presence of children may also deter migration because the cost of migration increases, it could be that the presence of children under five in the household has a positive effect on migration when the data are collected after the potential move, as in our case.

\section{Data, variables, and method}

We used data from the Indonesian population census (PC2000 and PC2010) and the Indonesian Intercensal Survey 2005 (SUPAS). SUPAS was designed to provide demographic data complementary to population censuses. The use of SUPAS data along with PC2000 and PC2010 allows a more detailed analysis of migration during the 2000-2010 period by providing an extra time point. We used the full SUPAS data and a $0.5 \%$ sample of the total population from the census data. We used a variable year to capture the differences in overall levels of migration between the periods. Furthermore, we ran the models separately for the three separate years as a sensitivity analysis.

An alternative dataset we could have used is the Indonesia Family Life Survey (IFLS) data. IFLS is an on-going longitudinal survey that started in 1993 and covers 13 out of the 27 provinces in Indonesia, and $83 \%$ of the population. The initial observation of IFLS 1993 was over 30,000 individuals in over 7000 households. The latest IFLS (conducted in 2014) covers around 50,000 individuals in around 16,000 households (Strauss et al. 2016). Although this is a large sample, it is not large enough to study migration distinguished by type of origin combined with type of destination. A major advantage of the data we used compared with IFLS is that our data cover all Indonesian regions up to district level (kabupaten/kota), and offer a sample size allowing us to distinguish types of migration in a detailed way.

We limit our analysis to those aged 15 years and over to consider autonomous decision-making on migration. The reason for starting our analysis as early as age 15 years was because for the case of Indonesia, the transition from basic education (primary school/Sekolah Dasar and junior high school/Sekolah Menengah Pertama) to senior high school/Sekolah Menengah Umum/Atas, in general, occurs at age 15 or over. It is common in Indonesia that students leave their parental home around this age to pursue higher education (Sekolah Menengah Umum/Atas or higher). 
The size of the analytical sample for 2000 is 694,492 observations, 758,092 observations for 2005 and 845,134 observations for 2010. These samples may seem huge but, because of the detail we apply in distinguishing between migration origins and destinations, we occasionally still end up with small numbers of moves. For example, the number of observed persons aged 70+ living in Jakarta in 2000, 2005 and 2010 were 527, 605 and 826. However, in 2005, there was no observation for people aged $70+$ who migrated from Jakarta to another metro area (the same was true for migrants from metro areas to other metro areas).

We define migration as a change of residence to a different area during a fiveyear observation interval (recent migration), distinguished by the type of origin and destination (see Table 1 for details). We identified the changes of residence by comparing current and previous residence. Such data are usually referred to as transition data (Rogers et al. 2001). With a small modification from the age grouping by Warnes (1992), we measured age by grouping individuals into five age groups: 15-22 (education age), 23-29 (labour-market entry and family formation age), 30-54 (family age), 55-69 (retirement age) and 70+ years (older age). The other explanatory variables are gender, educational attainment, labour market participation status, marital status and the presence of children under five years in the household (see Table 1 for a description of the categories). To measure educational attainment, we grouped primary and junior high school into one category (basic education) because in the context of Indonesia both form part of a 9-year program of compulsory education (SD and SMP Sederajat).

Compared to longitudinal data that provide individual characteristics before the potential move (as available in IFLS), the data we used suffer from some limitations. First, the five-year transition data do not provide a completely comprehensive count of the migrant population. Persons who migrated during the interval but died before being counted on the day of the census or survey are omitted, and multiple moves_-including moves back and forth-are not recorded. Second, the data are cross-sectional: all explanatory variables are measured at the time of enumeration rather than before the potential move, and hence reflect the characteristics of the person after the migration decision has been made. This measurement could be imprecise for those variables that in fact change through time. This measurement error holds for labour market participation, level of education, marital status and the presence of children under 5 in the household. For example, for people migrating for a better job or marriage, the job or marital status they acquired after migration cannot be seen as causing the move. And if a child is under five after a potential move, it may not even have been born before the move. This is certainly a downside, and it implies that the estimated effects cannot be interpreted as causal effects, but as indicating sources of differentiation between migrants and stayers. However, there is still much that can be learned from a detailed analysis of cross-sectional data. In particular, it is possible to gain insight into the age distribution of migration events by type and the way in which individual characteristics are related to different types of migration.

As an analytical strategy, we use multinomial logistic regression models to analyse factors differentiating migrants of the different types from stayers. Although we use the term 'effects' for readability, we interpret the estimated effects as associations 
Table 1 Definition of variables

\begin{tabular}{|c|c|}
\hline Variable & Definition \\
\hline Migstat & $\begin{array}{l}\text { Dependent variable (migration status): } \\
\text { For Jakarta inhabitants: } \\
\text { Move to a metro area within commuting distance } \\
\text { Move to another metro area } \\
\text { Move to non-metro area } \\
\text { Stay in Jakarta (reference category) } \\
\text { For inhabitants of other metro areas: } \\
\text { Move to Jakarta } \\
\text { Move to another metro area } \\
\text { Move to non-metro area } \\
\text { Stay in current metro area (reference category) } \\
\text { For inhabitants of non-metro areas: } \\
\text { Move to Jakarta } \\
\text { Move to another metro area } \\
\text { Move to non-metro area } \\
\text { Stay in current non-metro area (reference category) }\end{array}$ \\
\hline Age & $\begin{array}{l}\text { Age group: } \\
\text { 15-22 years } \\
23-29 \text { years } \\
30-54 \text { years } \\
55-69 \text { years } \\
70+\text { years (reference category) }\end{array}$ \\
\hline Year & $\begin{array}{l}\text { Period of observation: } \\
2000 \text { (reference category) } \\
2005 \\
2010\end{array}$ \\
\hline Sex & $\begin{array}{l}\text { Sex: } \\
\text { Male } \\
\text { Female (reference category) }\end{array}$ \\
\hline Educ & $\begin{array}{l}\text { Educational attainment: } \\
\text { Did not finish compulsory education (reference category) } \\
\text { Finished compulsory education (primary and junior high school/SD and SMP sederajat) } \\
\text { Finished senior high school/SMA sederajat } \\
\text { Finished Diploma/University }\end{array}$ \\
\hline Jobstat & $\begin{array}{l}\text { Labour market participation status: } \\
\text { Working in the formal sector (reference category) } \\
\text { Not in the labour market including unemployed } \\
\text { Working in the informal agriculture sector } \\
\text { Working in the informal non-agriculture sector }\end{array}$ \\
\hline
\end{tabular}


Table 1 continued

\begin{tabular}{ll}
\hline Variable & Definition \\
\hline Marstat & Marital status: \\
& Never married \\
& Married (reference category) \\
& Divorced \\
& Widowed \\
& Presence of children under five years in the household: \\
Under5 & No children under five (reference category) \\
& Under-five present \\
\hline
\end{tabular}

rather than causal effects. For the regional classification, we follow Wajdi et al. (2015) who divided Indonesia into 13 regions consisting of metropolitan and nonmetropolitan areas. They constructed this classification on the basis of Government Regulation no. 26 (2008) and data on metropolitan agglomeration size published by the World Bank (2012). Each region consists of administrative areas below the provincial level, namely, districts (kabupaten) and municipalities (kota). A description and maps of the regions are given in Appendices 1-3. We categorize these 13 regions into three categories: Jakarta, other metropolitan areas, and non-metropolitan areas. We estimated separate models for these three origins.

\section{Results}

We first present the percentage of each migration type by age group (Figs. 1, 2, 3) in $\mathrm{z}$-scores representing the age migration profile. The general pattern resembles the standard age migration schedule, that is, young adults around age 15-29 have the highest migration propensity.

We find the peak at age 15-22 for out-migration from Jakarta to other metro areas, from non-metro areas to Jakarta and from non-metro areas to other metro areas. This finding is as expected because those in this age group, that is, an education age, will move to areas where they can find better education facilitiesJakarta and other metro areas. For most other types, we find the peak at age 23-29.

A notable exception is migration from Jakarta to the nearby metro area: this type is just as common at age $30-54$ as at age $23-29$. This finding is in line with the idea that families, and those beyond the age of labour-market entry, are likely to move short distances in search of a better residential environment or low-cost housing.

After it reaches its peak around 15-29 years, the migration propensity then declines up to retirement age, 55-69 years. We then find an increasing likelihood of migrating for the oldest age group $(70+)$ for some types, namely, out-migration from Jakarta to metro areas within commuting distance and to other metro areas; migration from other metro areas to other metro areas; and migration from other metro areas to non-metro areas. These higher migration propensities are likely related to finding more comfortable places offering a better residential environment, or places where more care was available. 


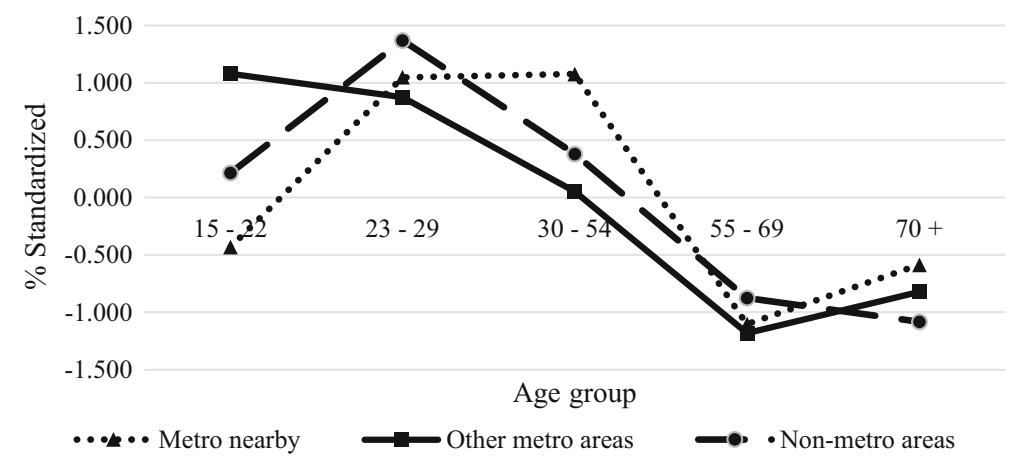

Fig. 1 Standardized percentage of people migrating from Jakarta by age group

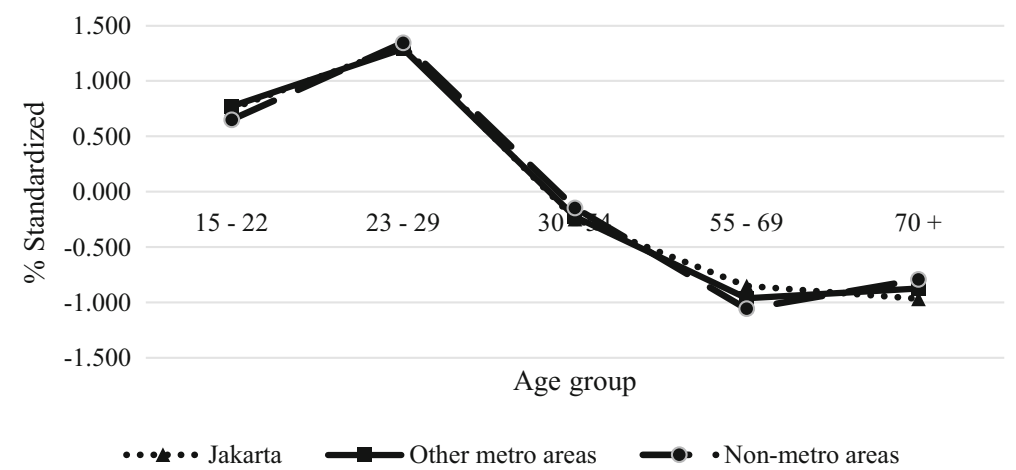

Fig. 2 Standardized percentage of people migrating from other metros by age group

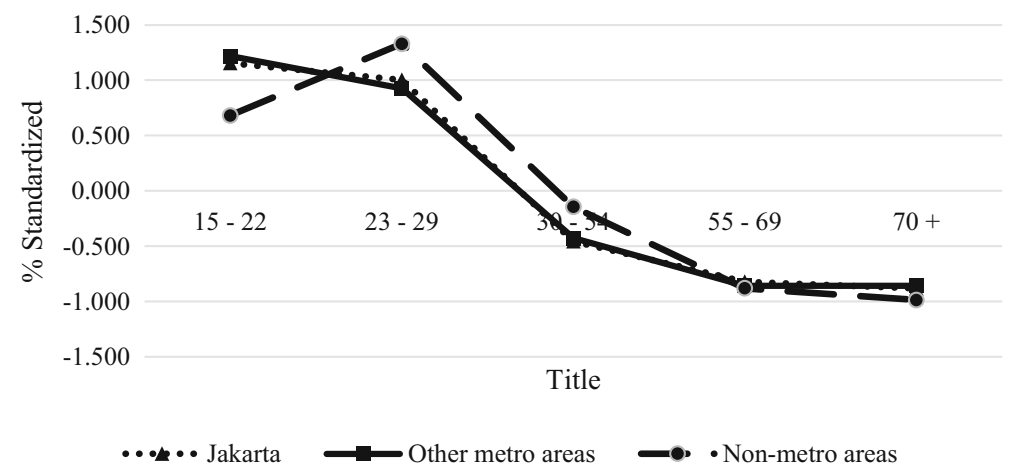

Fig. 3 Standardized percentage of people migrating from non-metros by age group

As can be seen from the descriptive statistics in Appendices 4-6, for most migration types the percentage of people migrating shows a decrease from 2000 to 2005, but a slight increase between 2005 and 2010. As an exception, migration from Jakarta to non-metro areas increased for the period of 2000 to 2010. In general, 
males were more likely to migrate than females, except for migration from nonmetro areas to Jakarta. For the level of educational attainment, labour market participation status, marital status and the presence of children under five, the findings are clearly influenced by the measurement after a potential move. For example, whereas for most migration types those who worked in the formal sector were more likely to migrate than those in other labour market participation statuses, migration from Jakarta to non-metro areas is a noteworthy exception: the percentage of people migrating from Jakarta to non-metro areas was $32.0 \%$ among those working in the informal agriculture sector. Undoubtedly, this finding is caused by the fact that very few people who live in Jakarta work in informal agriculture, while many of those who move from Jakarta to rural areas start working in that sector after the move. Another example is that some types of migration were more prevalent among those with children under five in the household than among those with no children under five in the household. Many of these are probably households that moved shortly before the child was born.

Tables 2, 3 and 4 present the results from our multinomial logistic regressions. The results for age largely confirm the pattern from our descriptive findings (Figs. 1, 2, 3). Males were less likely to migrate than females for some migration types, namely, migration from other metro areas to Jakarta (Model 4), migration from nonmetro areas to Jakarta (Model 7) and to other metro areas (Model 8). In contrast, migration from Jakarta to other metro areas (Model 2), and migration to non-metro areas from all origins (Models 3, 6 and 9), were more likely among males than females. These findings are in line with our idea that females are particularly likely to move to more developed areas compared to their previous place of residence, and males are particularly likely to move to less developed areas compared to their previous place of residence.

As expected, we found a positive effect of education on migration, i.e., the probability of migration increases with level of education. We found some specific patterns of migration from Jakarta, that is, those in the highest education level form the only category that has a significantly higher likelihood of migration for the case of migration from Jakarta to non-metro areas (Model 3); there is a negative effect of compulsory education and no significant effect of finishing senior education on migration from Jakarta to other metro areas (Model 2); there is a significant positive effect of higher education, but a non-significant negative effect for those who only finished compulsory education for the case of migration from Jakarta to a nearby metro area (Model 1). Furthermore, the largest effect of education on migration was found for migration from Jakarta to other metro areas within commuting distance, and, in particular, the highest likelihood of this type of migration was found for the "finished diploma/university" group. Another finding that also supports the positive effect of education on migration is that the fact that those who finished senior education have the highest likelihood of migrating from non-metro areas to Jakarta and other metro areas (Models 7 and 8). These findings are in line with our expectation for out-migration from Jakarta, given the location of one of the largest universities in Indonesia (the University of Indonesia) in Depok, a metro area within commuting distance from Jakarta. Since the data on the level of education were 
Table 2 Multinomial logit regression of the likelihood of migrating from Jakarta to: (i) another metro area within commuting distance, (ii) another metro area, and (iii) a non-metro area (odds ratios)

\begin{tabular}{|c|c|c|c|}
\hline \multirow[t]{3}{*}{ Variables } & \multicolumn{3}{|c|}{ Region of Origin: Jakarta } \\
\hline & \multirow{2}{*}{$\begin{array}{l}\text { Another metro within } \\
\text { commuting distance } \\
\text { (Model 1) }\end{array}$} & \multirow{2}{*}{$\begin{array}{l}\text { Another metro } \\
\text { area } \\
\text { (Model 2) }\end{array}$} & \multirow{2}{*}{$\begin{array}{l}\text { Non-metro } \\
\text { area }\end{array}$} \\
\hline & & & \\
\hline \multicolumn{4}{|l|}{ Age category } \\
\hline $15-22$ & $1.55 * * *$ & $4.06 * * *$ & $2.65 * * *$ \\
\hline $23-29$ & $1.46^{* * *}$ & $3.02 * *$ & $3.13 * * *$ \\
\hline $30-54$ & $1.33 * *$ & 2.15 & $1.93 * * *$ \\
\hline $55-69$ & $0.71 * *$ & 0.84 & 0.99 \\
\hline $70+$ (ref.) & 1.00 & 1.00 & 1.00 \\
\hline \multicolumn{4}{|l|}{ Period of measurement } \\
\hline 2000 (ref.) & 1.00 & 1.00 & 1.00 \\
\hline 2005 & $0.19 * * *$ & $0.33 * * *$ & 0.93 \\
\hline 2010 & $0.76^{* * *}$ & $0.72 * * *$ & 1.04 \\
\hline \multicolumn{4}{|l|}{ Sex } \\
\hline Male & 0.98 & $1.29 * *$ & $1.10 * *$ \\
\hline Female (ref.) & 1.00 & 1.00 & 1.00 \\
\hline \multicolumn{4}{|l|}{ Educational attainment } \\
\hline Did not finish compulsory education (ref.) & 1.00 & 1.00 & 1.00 \\
\hline Finished compulsory education & 0.93 & $0.44 * * *$ & 0.97 \\
\hline Finished senior education & $1.80 * * *$ & 0.96 & 1.15 \\
\hline Finished Diploma/University & $2.53 * * *$ & $1.51^{*}$ & $1.57 * * *$ \\
\hline \multicolumn{4}{|l|}{ Job status } \\
\hline Working in the formal sector (ref.) & 1.00 & 1.00 & 1.00 \\
\hline Not in the labour market or unemployed & 1.01 & $1.36^{* * *}$ & $1.23 * * *$ \\
\hline Informal agriculture & 1.00 & $6.36^{* * *}$ & $19.69 * * *$ \\
\hline Informal non-agriculture & 1.00 & 1.12 & $1.68 * * *$ \\
\hline \multicolumn{4}{|l|}{ Marital status } \\
\hline Never married & $0.48 * * *$ & $0.79 *$ & $0.75 * * *$ \\
\hline Divorced & 0.88 & 1.67 & $1.49 * * *$ \\
\hline Widowed & $0.76 * * *$ & 1.37 & $0.65 * * *$ \\
\hline Married (ref.) & 1.00 & 1.00 & 1.00 \\
\hline \multicolumn{4}{|l|}{ Presence of child under five in the household } \\
\hline No child under five (ref.) & 1.00 & 1.00 & 1.00 \\
\hline Child under five present & $2.25 * * *$ & $1.59 * *$ & $1.81 * * *$ \\
\hline Number of obs. & 98,830 & & \\
\hline Wald $\operatorname{chi}^{2}(48)$ & 3668 & & \\
\hline Prob $>$ chi $^{2}$ & 0.0000 & & \\
\hline Pseudo $\mathrm{R}^{2}$ & 0.0533 & & \\
\hline Log pseudolikelihood & $-35,192$ & & \\
\hline
\end{tabular}

$* p<0.10 ; * * p<0.05 ; * * * p<0.01$ 
Table 3 Multinomial logit regression of the likelihood of migrating from a metro area to: (i) Jakarta, (ii) another metro area, and (iii) a non-metro area (odds ratios)

\begin{tabular}{|c|c|c|c|}
\hline \multirow[t]{3}{*}{ Variables } & \multicolumn{3}{|c|}{ Region of Origin: another metro area } \\
\hline & \multirow{2}{*}{$\frac{\text { Jakarta }}{\text { (Model 4) }}$} & \multirow{2}{*}{$\frac{\text { Another metro area }}{\text { (Model 5) }}$} & \multirow{2}{*}{$\frac{\text { Non-metro area }}{(\text { Model 6) }}$} \\
\hline & & & \\
\hline \multicolumn{4}{|l|}{ Age category } \\
\hline $15-22$ & $3.75 * * *$ & $1.71 * *$ & $1.84 * * *$ \\
\hline $23-29$ & $3.75 * * *$ & $1.54 *$ & $1.95 * * *$ \\
\hline $30-54$ & $1.77 * *$ & 0.91 & $1.16^{*}$ \\
\hline $55-69$ & 1.11 & 0.70 & $0.69 * * *$ \\
\hline $70+$ (ref.) & 1.00 & 1.00 & 1.00 \\
\hline \multicolumn{4}{|l|}{ Period of measurement } \\
\hline 2000 (ref.) & 1.00 & 1.00 & 1.00 \\
\hline 2005 & $1.13 *$ & $0.34 * * *$ & $0.81 * * *$ \\
\hline 2010 & $0.69 * * *$ & $0.64 * * *$ & $0.50 * * *$ \\
\hline \multicolumn{4}{|l|}{ Sex } \\
\hline Male & $0.78 * * *$ & 0.95 & $1.06 * * *$ \\
\hline Female (ref.) & 1.00 & 1.00 & 1.00 \\
\hline \multicolumn{4}{|l|}{ Educational attainment } \\
\hline Did not finish compulsory education (ref.) & 1.00 & 1.00 & 1.00 \\
\hline Finished compulsory education & $1.78 * * *$ & $1.27 *$ & $1.35^{* * *}$ \\
\hline Finished senior education & $2.47 * * *$ & $3.00 * * *$ & $2.13 * * *$ \\
\hline Finished diploma/university & $4.28 * * *$ & $4.59 * * *$ & $3.33 * * *$ \\
\hline \multicolumn{4}{|l|}{ Job status } \\
\hline Working in the formal sector (ref.) & 1.00 & 1.00 & 1.00 \\
\hline Not in the labour market or unemployed & $0.40 * * *$ & $0.62 * * *$ & $0.92 * * *$ \\
\hline Informal agriculture & $0.01 * * *$ & $0.13 * * *$ & $1.59 * * *$ \\
\hline Informal non-agriculture & $0.56^{* * *}$ & 0.98 & $1.09 * * *$ \\
\hline \multicolumn{4}{|l|}{ Marital status } \\
\hline Never married & $1.26 * * *$ & 1.11 & 1.03 \\
\hline Divorced & 1.17 & 1.09 & $1.18 * *$ \\
\hline Widowed & 1.12 & 0.87 & 1.03 \\
\hline Married (ref.) & 1.00 & 1.00 & 1.00 \\
\hline \multicolumn{4}{|l|}{ Presence of a child under five in the household } \\
\hline No child under five (ref.) & 1.00 & 1.00 & 1.00 \\
\hline Child under five present & $1.89 * * *$ & $2.59 * * *$ & $2.04 * * *$ \\
\hline Number of obs. & 349,190 & & \\
\hline Wald $\operatorname{chi}^{2}(48)$ & 6143 & & \\
\hline Prob $>\mathrm{chi}^{2}$ & 0.0000 & & \\
\hline Pseudo $\mathrm{R}^{2}$ & 0.0462 & & \\
\hline Log pseudolikelihood & $-68,203$ & & \\
\hline
\end{tabular}

$* p<0.10 ; * * p<0.05 ; * * * p<0.01$ 
Table 4 Multinomial logit regression of the likelihood of migrating from a non-metro area to: (i) Jakarta, (ii) another metro area, and (iii) a non-metro area (odds ratios)

\begin{tabular}{|c|c|c|c|}
\hline \multirow[t]{3}{*}{ Variables } & \multicolumn{3}{|c|}{ Region of Origin: non-metro area } \\
\hline & \multirow{2}{*}{$\frac{\text { Jakarta }}{(\text { Model 7) }}$} & \multirow{2}{*}{$\frac{\text { Another metro area }}{\text { (Model 8) }}$} & \multirow{2}{*}{$\frac{\text { Non-metro area }}{\text { (Model 9) }}$} \\
\hline & & & \\
\hline \multicolumn{4}{|l|}{ Age category } \\
\hline $15-22$ & $7.67 * * *$ & $2.86^{* * *}$ & $3.00 * * *$ \\
\hline $23-29$ & $6.41 * * *$ & $1.99 * * *$ & $3.29 * * *$ \\
\hline $30-54$ & $2.27 * * *$ & 0.93 & $1.73 * * *$ \\
\hline $55-69$ & 1.13 & $0.78 * *$ & 1.07 \\
\hline $70+$ (ref.) & 1.00 & 1.00 & 1.00 \\
\hline \multicolumn{4}{|l|}{ Period of measurement } \\
\hline 2000 (ref.) & 1.00 & 1.00 & 1.00 \\
\hline 2005 & $0.58 * * *$ & $0.18^{* * *}$ & $0.63 * * *$ \\
\hline 2010 & $0.82 * * *$ & $0.68 * * *$ & $0.82 * * *$ \\
\hline \multicolumn{4}{|l|}{ Sex } \\
\hline Male & $0.58 * * *$ & $0.78 * * *$ & $1.14 * * *$ \\
\hline Female (ref.) & 1.00 & 1.00 & 1.00 \\
\hline \multicolumn{4}{|l|}{ Educational attainment } \\
\hline Did not finish compulsory education (ref.) & 1.00 & 1.00 & 1.00 \\
\hline Finished compulsory education & $2.12 * * *$ & $1.91 * * *$ & $1.39 * * *$ \\
\hline Finished senior education & $2.23 * * *$ & $4.26 * * *$ & $2.27 * * *$ \\
\hline Finished diploma/university & $1.53 * * *$ & $3.26 * * *$ & $2.46 * * *$ \\
\hline \multicolumn{4}{|l|}{ Job status } \\
\hline Working in the formal sector (ref.) & 1.00 & 1.00 & 1.00 \\
\hline Not in the labour market or unemployed & $0.13 * * *$ & $0.29 * * *$ & $0.51 * * *$ \\
\hline Informal agriculture & $0.00 * * *$ & $0.07 * * *$ & $0.33 * * *$ \\
\hline Informal non-agriculture & $0.33 * * *$ & $0.48 * * *$ & $0.70 * * *$ \\
\hline \multicolumn{4}{|l|}{ Marital status } \\
\hline Never married & $1.60 * * *$ & $1.12 * * *$ & $1.05 *$ \\
\hline Divorced & $1.19 *$ & 0.98 & 1.11 \\
\hline Widowed & 1.12 & $0.84 * *$ & $0.86 * *$ \\
\hline Married (ref.) & 1.00 & 1.00 & 1.00 \\
\hline \multicolumn{4}{|l|}{ Presence of a child under five in the household } \\
\hline No child under five (ref.) & 1.00 & 1.00 & 1.00 \\
\hline Child under five present & $1.82 * * *$ & $2.12 * * *$ & $1.71 * * *$ \\
\hline \multicolumn{4}{|l|}{$* p<0.10 ; * * p<0.05 ; * * * p<0.01$} \\
\hline Number of obs. & $1,839,197$ & & \\
\hline Wald $\operatorname{chi}^{2}(48)$ & 29,902 & & \\
\hline Prob $>\mathrm{chi}^{2}$ & 0.0000 & & \\
\hline Pseudo $\mathrm{R}^{2}$ & 0.1003 & & \\
\hline Log pseudolikelihood & $-197,443$ & & \\
\hline
\end{tabular}


recorded after migration, this finding is most likely partly due to migration to enrol in higher education.

The effects of labour market participation status on migration are mixed and show a specific pattern for each migration type. There are no significant effects of labour market participation status on migration from Jakarta to other metro areas within commuting distance (Model 1). In contrast, the effects of labour market participation on migration from Jakarta to non-metro areas (Model 3) are highly significant. For migration from Jakarta to other metro areas (Model 2), the likelihood of migration does not differ significantly between those who worked in the informal non-agriculture sector compared to those who worked in the formal sector.

For Models 2 and 3, the highest likelihood of migrating was found among those working in the informal agriculture. Those who worked in the formal sector were more likely to migrate from other metro areas to Jakarta or to another metro area than other job statuses (Models $4 \& 5$ ), but less likely to move from other metro areas to a non-metro area than those who worked in the informal sector (Model 6). For Models 7-9, the effects were consistent and highly significant, that is, those who worked in the formal sector were more likely to migrate from non-metro areas to all possible destinations than those in other job statuses.

Since the labour market participation status was recorded after the potential move, it is highly likely that those who migrated from Jakarta to another metro area and to non-metro areas (Models 2 and 3), and those who migrated from another metro area to a non-metro area (Model 6) changed their employment sector for better opportunities to get a job. The most obvious evidence is the high likelihood of migration to non-metro areas, where agriculture is dominant, for those who were working in informal agriculture. A similar argument holds for migration from nonmetro areas, where those who were working in a formal job had the highest likelihood of migrating. The findings also indicate that people working in the formal sector were more likely to move to areas where they can improve their wellbeing or their skills, that is, to more developed areas.

Our findings on the effect of marital status on migration from Jakarta seem to be partly in contrast with the general migration literature. Never-married persons were more likely to move from another metro area to Jakarta than married people (as one would expect), but less likely to migrate from Jakarta. Referring to the limitations of our data, married people migrating from Jakarta included those who were single before migration and migrated to get married. Thus, when it comes to union formation, those who migrated for marriage were probably highly likely to choose an affordable area but with metro ambiance or close to Jakarta. Divorced people were more likely to move to non-metro areas than married people whereas widowed people were more likely to move to another metro area within commuting distance or to a non-metro area. Those who had dependent children under five (including those whose children were born shortly after a potential move) were more likely to migrate than those who had no young dependent children, and this effect was highly statistically significant. The results from Tables 5, 6 and 7 in the Appendix section also show that those who had children under five and lived in Jakarta were likely to migrate to a metro area within commuting distance; those who had children under 
five and lived in another metro area were likely to migrate to a similar area (metro to metro migration); but those who had children under five and lived in non-metro area were likely to migrate to a metro area (non-metro to metro migration).

The results of the three separate models for the years 2000, 2005 and 2010 (available from the authors on request) were not too different from those of the pooled model. Owing to empty cell problems for migration from Jakarta to other metro areas and from metro areas to other metro areas, the models for 2005 for these types of migration did not produce reliable estimates of the effect of age. For most variables in most models, the coefficients were similar for the three separate years or at least in the same direction, although some were not statistically significant. A few coefficients differed in direction between the years. In the pooled model there are no significant effects of labour market participation status on migration from Jakarta to other metro areas within commuting distance (Model 1 in Table 2), but in the model for 2005 those who worked in the informal sector were less likely to moved compared to those who worked in the formal sector and in the model for 2010 this was true for those who worked in the informal non-agriculture sector. The finding that never-married persons were less likely than married persons to migrate from Jakarta was reversed for moves to other metro areas in 2010. For migration from other metro areas to other metro areas (Model 6), there were also some deviations in the coefficients of the separate models compared with those of the pooled model. Those who were unemployed or not in the labour market were estimated to be less likely to move than those who worked in the formal sector in the full model, but in 2005, this was estimated to be the other way around. Never-married and widowed persons were estimated to be just about as likely to move as married persons in the full model, but never-married persons were less likely to move than married persons in 2000 and 2005, and widowed persons were less likely to move than married persons in 2005 and 2010. The only deviation for migration from non-metro areas was found for the coefficient for never-married compared with married people in the year 2000. In the pooled model, this effect was estimated to be positive, but it was negative for the year 2000 .

\section{Conclusion and discussion}

We investigated to what extent the life-course characteristics of an individual would be associated with different types of migration in the Indonesian context. We found that migration varied with age and life-course characteristics, mostly in rather predictable ways. Our findings also show that different characteristics are associated with different migration outcomes. We find indications that both educational and/or job opportunities and environment play a part, but in different ways depending on the type of migration. Some of our findings were counter-intuitive at first sight, for example, the presence of children under five had a highly statistically significant positive effect while it was expected to be a deterrent to migration. This finding is likely caused by the measurement of the independent variables after the potential move.

It should be noted that different preferences for migration destinations operate most likely through different migration motives. For example, for young adults, education and job opportunities motives are likely to be dominant factors behind the 
location choice, whereas in later life the need for housing or a better environment may become important as the driving force behind the location choice.

The data we use in this research certainly have limitations. The fact that the data are cross-sectional, and thus do not contain information about the individuals' situation before a potential move, is the most important of these. This makes it difficult to interpret the regression results as causal. Yet, there is still much that can be learned from a detailed analysis of cross-sectional data. In our case, we have a greater sample size and coverage of a larger number of regions compared to existing longitudinal data (e.g., the Indonesian Family Life Survey/IFLS data), which allows us to distinguish between types of migration. This distinction allows us to gain insight into the age distribution of migration events by type and the way in which an individual's characteristics are related to different types of migration. Nevertheless, it would be useful to complement our analyses with analyses of IFLS data, making use of IFLS' better opportunities for analyses allowing a causal interpretation of results. It is also clear that caution should be used when pooling data for different time points. In our case the findings were not very different between analyses for three separate years.

Previous studies on the macro pattern of migration in Indonesia have shown that migration was mainly directed toward more developed regions and that interregional migration in Indonesia is predominantly a response to pull rather than to push forces. However, the link between micro characteristics of migrants and the macro context is rarely studied, especially for the case of Indonesia. Therefore, in order to understand the migration phenomenon in Indonesia in a more comprehensive way, it is necessary to further investigate interregional migration by linking the micro characteristics and macro context of migrants, e.g., by using an agent-based modelling approach for further research on inter-regional migration in Indonesia.

Wajdi (2010) showed that the main reasons for migration were economic, family and education reasons, while our own findings suggest that migration is likely related to a search for better education or jobs. In the framework of population redistribution, our own and previous research therefore suggests that to attract migration, it is necessary to create new economic centres as well as education centres (amenities) for better education and better job opportunities, not only in Java but also outside Java. Java is currently known as the centre of amenities, ranging from education facilities to business or economic activities. Therefore it is necessary to develop new educational centres outside Java that affiliate with education facilities in Java. This strategy could increase the diversity in educational choices. An example could be creating collaborations between universities in Java and universities outside Java. Developing new economic centres is also crucial. Batam is an example of the successful development of new industrial centres outside Java.

Open Access This article is distributed under the terms of the Creative Commons Attribution 4.0 International License (http://creativecommons.org/licenses/by/4.0/), which permits unrestricted use, distribution, and reproduction in any medium, provided you give appropriate credit to the original author(s) and the source, provide a link to the Creative Commons license, and indicate if changes were made. 


\section{Appendix 1}

\section{See Table 5.}

Table 5 Summary of the division of Indonesia into 13 regions

\begin{tabular}{ll}
\hline Region's Name & Remark \\
\hline 1. Jakarta & Jakarta (The Special Capital Region of Jakarta/DKI Jakarta) is the \\
& capital city of Indonesia. Jakarta consists of 1 district (Ind: \\
& Kabupaten) namely Kepulauan Seribu and 5 municipalities (Ind: \\
& Kota), namely: Jakarta Selatan, Jakarta Timur, Jakarta Pusat, \\
Jakarta Barat and Jakarta Utara & The area surrounding Jakarta, consists of 3 districts (i.e.: Bogor, \\
& Bekasi and Tangerang) and 4 municipalities (i.e.: Kota Bogor, Kota \\
2. Bodetabek & Bekasi, Kota Depok, and Kota Tangerang) \\
& The metropolitan area located in West Java Province, consists of 2 \\
3. Bandung Raya & Bandung (Bandung and Bandung Barat) and 2 municipalities (Kota
\end{tabular}

4. Rest of West Java and Banten The areas in West Java and Banten Provinces except Bodetabek and (RoWJB)

\section{Kedungsepur \\ 6. Rest of Central Java and Yogyakarta (RoCJY) \\ 7. Gerbangkertosusila}

8. Rest of East Java (RoEJ)

9. Mebidangro

10. Rest of Sumatera (RoS)

11. Kalimantan

12. Sulawesi

13. Rest of Indonesia (RoI)
Bandung Raya

The metropolitan area located in Central Java Province, consists of 4 districts (Grobogan, Demak, Semarang and Kendal) and 2 municipalities (Kota Salatiga and Kota Semarang)

The areas in Central Java and Yogyakarta Provinces except Kedungsepur Metropolitan Areas

Gerbangkertosusila stands for Gresik, Bangkalan, Mojokerto, Surabaya, Sidoarjo and Lamongan, a metropolitan area located in East Java Province which consists of 5 districts (Sidoarjo, Mojokerto, Lamongan, Gresik, Bangkalan) and 2 municipalities (Kota Mojokerto and Kota Surabaya)

Consists of areas in East Java Province, the eastern part of Java Island, except the Gerbangkertosusilo Metropolitan area

Mebidangro is an acronym for Medan, Binjai, Deli Serdang and Tanah Karo, a metropolitan area located in Sumatera Island. This metropolitan area consists of 2 districts (Karo and Deli Serdang) and 2 municipalities (Kota Medan and Kota Binjai)

Consists of areas in Sumatera Island, except Mebidangro

Kalimantan is also known as Borneo, one of the 5 biggest islands in Indonesia, consists of 5 Provinces

Sulawesi is also known as Celebes, one of the 5 biggest islands in Indonesia, consists of 6 Provinces

Consists of 7 provinces namely: Bali, West Nusa Tenggara (NTB), East Nusa Tenggara (NTT), Maluku, North Maluku, Papua and West Papua. Papua (also known as Irian Jaya) is the biggest island in this region, which covers $21.8 \%$ of Indonesia's territory. During the Dutch colonization, this region was called Outer Indonesia, while during the New Order era, this region was called Indonesia Bagian Timur (The Eastern Part of Indonesia)

Source: Author's compilation 


\section{Appendix 2}

See Fig. 4.

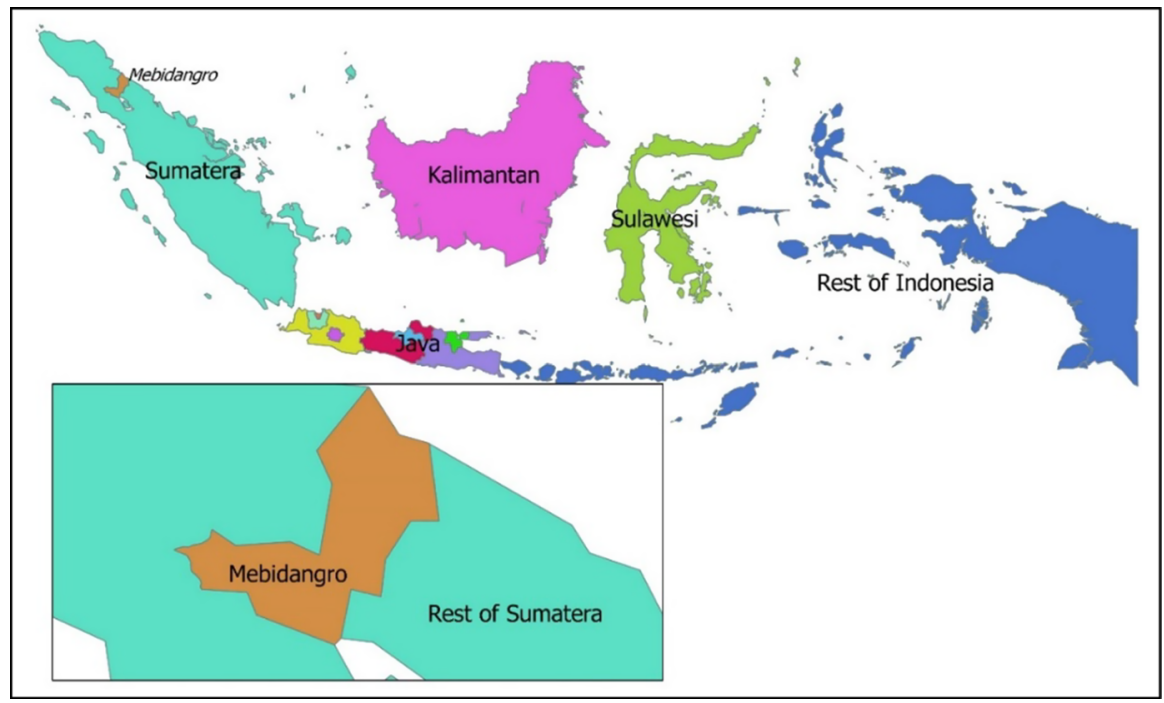

Fig. 4 Map of Indonesia (inset: Map of Mebidangro)

\section{Appendix 3}

See Fig. 5.

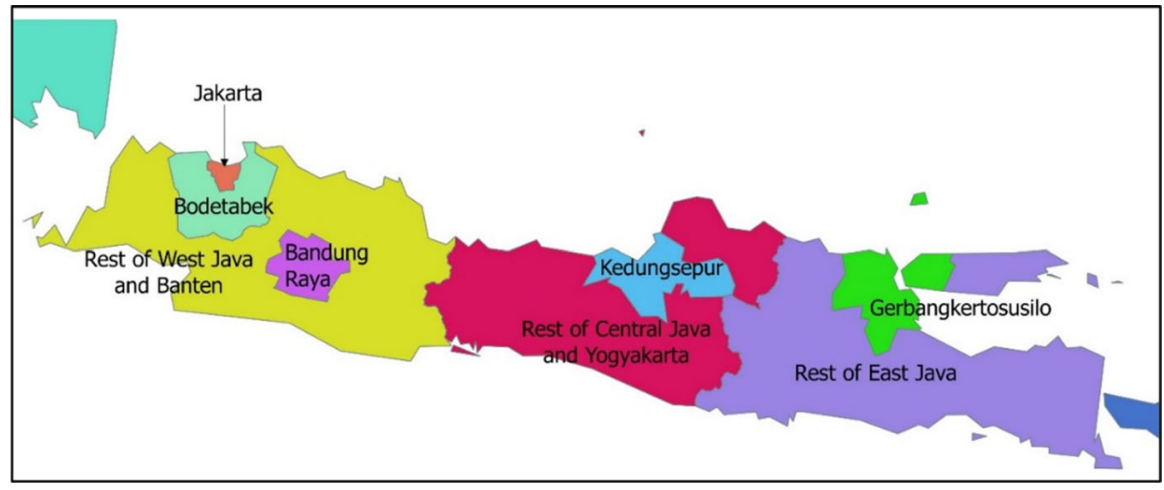

Fig. 5 Map of Java Island 


\section{Appendix 4}

See Table 6.

Table 6 Percentage of Jakarta inhabitants by type of migration $(\mathrm{N}=98,830)$

\begin{tabular}{|c|c|c|c|c|}
\hline \multirow[t]{2}{*}{ Variables } & \multicolumn{3}{|c|}{ Percentage migrating to: } & \multirow{2}{*}{$\begin{array}{l}\text { Percentage } \\
\text { in sample }\end{array}$} \\
\hline & $\begin{array}{l}\text { Another metro } \\
\text { within commuting } \\
\text { distance }\end{array}$ & $\begin{array}{l}\text { Other metro } \\
\text { areas }\end{array}$ & $\begin{array}{l}\text { Non-metro } \\
\text { areas }\end{array}$ & \\
\hline \multicolumn{5}{|l|}{ Age category } \\
\hline $15-22$ & 3.8 & 0.6 & 3.0 & 19.5 \\
\hline $23-29$ & 5.9 & 0.6 & 4.4 & 21.7 \\
\hline $30-54$ & 5.9 & 0.4 & 3.2 & 48.5 \\
\hline $55-69$ & 2.9 & 0.2 & 1.7 & 8.4 \\
\hline $70+$ & 3.6 & 0.3 & 1.4 & 2.0 \\
\hline \multicolumn{5}{|l|}{ Period of measurement } \\
\hline 2000 & 7.2 & 0.7 & 3.0 & 32.4 \\
\hline 2005 & 1.9 & 0.3 & 3.7 & 30.3 \\
\hline 2010 & 6.2 & 0.5 & 3.2 & 37.3 \\
\hline \multicolumn{5}{|l|}{ Sex } \\
\hline Male & 5.2 & 0.5 & 3.6 & 50.5 \\
\hline Female & 5.2 & 0.4 & 3.0 & 49.5 \\
\hline \multicolumn{5}{|l|}{ Educational attainment } \\
\hline Did not finish compulsory education & 3.1 & 0.5 & 3.0 & 5.2 \\
\hline Finished compulsory education & 3.4 & 0.3 & 3.1 & 40.3 \\
\hline Finished senior education & 6.2 & 0.6 & 3.3 & 40.6 \\
\hline Finished Diploma/University & 8.3 & 0.7 & 3.9 & 13.9 \\
\hline \multicolumn{5}{|l|}{ Labour market participation status } \\
\hline Working in the formal sector & 6.1 & 0.5 & 2.8 & 37.1 \\
\hline $\begin{array}{l}\text { Not in the labour market or } \\
\text { unemployed }\end{array}$ & 4.6 & 0.5 & 2.8 & 44.1 \\
\hline Informal agriculture & 2.7 & 1.3 & 32.0 & 0.8 \\
\hline Informal non-agriculture & 4.9 & 0.4 & 4.0 & 17.9 \\
\hline \multicolumn{5}{|l|}{ Marital status } \\
\hline Never married & 3.4 & 0.6 & 3.0 & 31.0 \\
\hline Divorced & 5.0 & 0.6 & 4.5 & 1.6 \\
\hline Widowed & 3.0 & 0.3 & 1.4 & 4.1 \\
\hline Married & 6.2 & 0.5 & 3.5 & 63.3 \\
\hline \multicolumn{5}{|l|}{$\begin{array}{l}\text { Presence of a child under } 5 \text { in the } \\
\text { household }\end{array}$} \\
\hline No child under five & 5.3 & 0.5 & 3.0 & 90.4 \\
\hline Child under five present & 4.7 & 0.4 & 5.6 & 9.6 \\
\hline Total & 5.2 & 0.5 & 3.3 & 100.0 \\
\hline
\end{tabular}




\section{Appendix 5}

See Table 7.

Table 7 Percentage of inhabitants of other metro areas by type of migration $(\mathrm{N}=349,190)$

\begin{tabular}{|c|c|c|c|c|}
\hline \multirow[t]{2}{*}{ Variables } & \multicolumn{3}{|c|}{ Percentage migrating to: } & \multirow{2}{*}{$\begin{array}{l}\text { Percentage in } \\
\text { sample }\end{array}$} \\
\hline & Jakarta & $\begin{array}{l}\text { Other metro } \\
\text { areas }\end{array}$ & $\begin{array}{l}\text { Non-metro } \\
\text { areas }\end{array}$ & \\
\hline \multicolumn{5}{|l|}{ Age category } \\
\hline $15-22$ & 0.9 & 0.6 & 3.8 & 21.4 \\
\hline $23-29$ & 1.1 & 0.7 & 4.8 & 19.0 \\
\hline $30-54$ & 0.4 & 0.3 & 2.7 & 46.7 \\
\hline $55-69$ & 0.2 & 0.2 & 1.4 & 9.6 \\
\hline $70+$ & 0.1 & 0.2 & 1.8 & 3.3 \\
\hline \multicolumn{5}{|l|}{ Period of measurement } \\
\hline 2000 & 0.6 & 0.6 & 4.0 & 35.9 \\
\hline 2005 & 0.8 & 0.3 & 4.1 & 18.5 \\
\hline 2010 & 0.5 & 0.4 & 2.1 & 45.6 \\
\hline \multicolumn{5}{|l|}{$\operatorname{Sex}$} \\
\hline Male & 0.6 & 0.5 & 3.4 & 50.0 \\
\hline Female & 0.6 & 0.4 & 3.0 & 50.0 \\
\hline \multicolumn{5}{|l|}{ Educational attainment } \\
\hline Did not finish compulsory education & 0.2 & 0.2 & 1.9 & 12.6 \\
\hline Finished compulsory education & 0.5 & 0.3 & 2.7 & 51.3 \\
\hline Finished senior education & 0.8 & 0.7 & 4.0 & 28.4 \\
\hline Finished Diploma/University & 1.4 & 1.0 & 5.3 & 7.7 \\
\hline \multicolumn{5}{|l|}{ Labour market participation status } \\
\hline Working in the formal sector & 1.1 & 0.7 & 3.6 & 28.2 \\
\hline Not in the labour market or unemployed & 0.5 & 0.4 & 2.9 & 41.2 \\
\hline Informal agriculture & 0.0 & 0.0 & 3.5 & 11.2 \\
\hline Informal non-agriculture & 0.5 & 0.5 & 3.0 & 19.3 \\
\hline \multicolumn{5}{|l|}{ Marital status } \\
\hline Never married & 1.0 & 0.6 & 4.0 & 26.6 \\
\hline Divorced & 0.5 & 0.4 & 3.0 & 1.7 \\
\hline Widowed & 0.2 & 0.2 & 1.7 & 5.1 \\
\hline Married & 0.5 & 0.4 & 2.9 & 66.6 \\
\hline \multicolumn{5}{|c|}{ Presence of a child under five in the household } \\
\hline No child under five & 0.6 & 0.4 & 2.9 & 92.8 \\
\hline Child under five present & 1.2 & 0.6 & 6.1 & 7.2 \\
\hline Total & 0.6 & 0.4 & 3.2 & 100.0 \\
\hline
\end{tabular}




\section{Appendix 6}

See Table 8.

Table 8 Percentage of inhabitants of non-metro areas by type of migration $(\mathrm{N}=1,839,197)$

\begin{tabular}{|c|c|c|c|c|}
\hline \multirow[t]{2}{*}{ Variables } & \multicolumn{3}{|c|}{ Percentage migrating to: } & \multirow{2}{*}{$\begin{array}{l}\text { Percentage in } \\
\text { sample }\end{array}$} \\
\hline & Jakarta & $\begin{array}{l}\text { Other metro } \\
\text { areas }\end{array}$ & $\begin{array}{l}\text { Non-metro } \\
\text { areas }\end{array}$ & \\
\hline \multicolumn{5}{|l|}{ Age category } \\
\hline $15-22$ & 0.7 & 1.4 & 1.2 & 21.6 \\
\hline $23-29$ & 0.7 & 1.2 & 1.6 & 17.2 \\
\hline $30-54$ & 0.2 & 0.5 & 0.7 & 45.8 \\
\hline $55-69$ & 0.1 & 0.2 & 0.3 & 11.2 \\
\hline $70+$ & 0.0 & 0.2 & 0.3 & 4.2 \\
\hline \multicolumn{5}{|l|}{ Period of measurement } \\
\hline 2000 & 0.5 & 1.2 & 1.0 & 29.0 \\
\hline 2005 & 0.3 & 0.3 & 0.8 & 36.0 \\
\hline 2010 & 0.4 & 0.9 & 0.9 & 35.0 \\
\hline \multicolumn{5}{|l|}{ Sex } \\
\hline Male & 0.3 & 0.8 & 1.0 & 49.8 \\
\hline Female & 0.4 & 0.8 & 0.8 & 50.2 \\
\hline \multicolumn{5}{|l|}{ Educational attainment } \\
\hline Did not finish compulsory education & 0.1 & 0.2 & 0.4 & 22.4 \\
\hline Finished compulsory education & 0.4 & 0.6 & 0.8 & 54.8 \\
\hline Finished senior education & 0.6 & 1.8 & 1.6 & 18.6 \\
\hline Finished diploma/university & 0.6 & 1.5 & 1.9 & 4.2 \\
\hline \multicolumn{5}{|l|}{ Labour market participation status } \\
\hline Working in the formal sector & 1.2 & 2.2 & 1.8 & 16.7 \\
\hline Not in the labour market or unemployed & 0.2 & 0.7 & 0.8 & 36.5 \\
\hline Informal agriculture & 0.0 & 0.1 & 0.4 & 30.3 \\
\hline Informal non-agriculture & 0.3 & 0.7 & 1.0 & 16.6 \\
\hline \multicolumn{5}{|l|}{ Marital status } \\
\hline Never married & 0.7 & 1.4 & 1.3 & 25.8 \\
\hline Divorced & 0.3 & 0.6 & 0.8 & 1.8 \\
\hline Widowed & 0.1 & 0.2 & 0.3 & 6.0 \\
\hline Married & 0.2 & 0.6 & 0.8 & 66.5 \\
\hline \multicolumn{5}{|c|}{ Presence of a child under five in the household } \\
\hline No child under five & 0.3 & 0.8 & 0.9 & 86.7 \\
\hline Child under five present & 0.4 & 0.7 & 1.2 & 13.3 \\
\hline Total & 0.4 & 0.8 & 0.9 & 100.0 \\
\hline
\end{tabular}




\section{References}

Alatas, S. (1993). Macro patterns of internal migration in Indonesia, 1971-1990. Indonesian Journal of Demography, 20(40), 21-47.

Ananta, A., Anwar, E. N,. \& Miranti, R. (2001). Age-sex pattern of migrants and movers: A multilevel analysis on an Indonesian data set. Asian Metacentre Research Paper Series: National University of Singapore. http://w.populationasia.org/Publications/RP/AMCRP1.pdf. Accessed 5 May 2015.

Basker, E. (2003). Education, job search and migration. University of Missouri-Columbia Working Paper, (02-16). http://www.iza.org/en/webcontent/events/transatlantic/papers_2003/basker.pdf. Accessed 10 May 2015.

Bernard, A., Bell, M., \& Charles-Edwards, E. (2014). Life-course transitions and the age profile of internal migration. Population and Development Review, 40(2), 213-239.

Bernard, A., Bell, M., \& Charles-Edwards, E. (2016). Internal migration age patterns and the transition to adulthood: Australia and Great Britain compared. Journal of Population Research, 33, 123-146.

Biddle, N., \& Yap, M. (2010). Demographic and socioeconomic outcomes across the indigenous Australian lifecourse: Evidence from the 2006 census. Canberra: ANU E Press.

Boyle, P., Halfacree, K., \& Robinson, V. (1998). Exploring contemporary migration. New York: Addison Wesley Longman.

BPS - Statistics Indonesia. (2013a). Weight diagram for consumer price index Book 12012 [Diagram Timbang Indeks Harga Konsumen Buku 1 2012]. Jakarta: BPS-Statistics Indonesia.

BPS - Statistics Indonesia. (2013b). Weight diagram for consumer price index Book 22012 [Diagram Timbang Indeks Harga Konsumen Buku 2 2012]. Jakarta: BPS-Statistics Indonesia.

BPS - Statistics Indonesia. (2013c). Weight diagram for consumer price index Book 32012 [Diagram Timbang Indeks Harga Konsumen Buku 3 2012]. Jakarta: BPS-Statistics Indonesia.

Chotib. (1999). Model migration schedule for Jakarta and outside Jakarta: An analysis on the 1995 SUPAS data with multiregional demographic approach [Skedul model migrasi dari DKI Jakarta/ Luar DKI Jakarta: Analisis data SUPAS 1995 dengan pendekatan demografi multiregional]. Master Thesis. Graduate Program on Population and Labour Study, University of Indonesia, Indonesia.

Clark, W. A. V. (2013). Life course events and residential change: Unpacking age effects on the probability of moving. Journal of Population Research, 30(4), 319-334.

Clark, W. A. V., \& Huang, Y. (2003). The life course and residential mobility in British housing markets. Environment and Planning A, 35(2), 323-340.

Courgeau, D. (1985). Migration, family, and career: A life course approach. In P. B. Baltes, D. L. Featherman, \& R. M. Lerner (Eds.), Life-span delopment and behaviour (Vol. 10, pp. 219-255). New York: Psychology Press.

Darmawan, B. \& Chotib. (2007). Estimated migration patterns among provinces in Indonesia based on the index of economic attraction. In Paper presented in parallel session IIIC of poverty, population and health conference, Jakarta, Indonesia.

DaVanzo, J. (1978). Does unemployment affect migration? Evidence from micro data. The Review of Economics and Statistics, 60(4), 504-514.

De Groot, C., Mulder, C. H., Das, M., \& Manting, D. (2011). Live events and the gap between intention to move and actual mobility. Environment and Planning A, 43, 48-66.

De Jong, G. F. (2000). Expectations, gender, and norms in migration decision-making. Population Studies, 54(3), 307-319.

De Jong, G. F., \& Gardner, R. W. (1981). Migration decision making: Multidisciplinary approaches to microlevel studies in developed and developing countries. New York: Pergamon Press.

Elder, G. H., Jr. (1994). Time, human agency, and social change: Perspectives on the life course. Social Psychology Quarterly, 57, 4-15.

Elder, G. H., Jr., Johnson, M. K., \& Crosnoe, R. (2003). The emergence and development of life course theory. In J. T. Mortimer \& M. J. Shanahan (Eds.), Handbook of the life course (pp. 3-22). New York: Kluwer.

Feliciano, C. (2005). Educational selectivity in US immigration: How do immigrants compare to those left behind? Demography, 42(1), 131-152.

Findlay, A., McCollum, D., Coulter, R., \& Gayle, V. (2015). New mobilities across the life course: A framework for analysing demographically linked drivers of migration. Population, Space and Place, 21(4), 390-402. 
Firman, T. (1994). Inter-province migration and area development in Indonesia [Migrasi Antarprovinsi dan Pengembangan Wilayah di Indonesia]. Prisma, 7(XXIII), 3-15.

Fischer, P. A., \& Malmberg, G. (2001). Settled people don't move: On life course and (im-) mobility in Sweden. International Journal of Population Geography, 7(5), 357-371.

Greenwood, M. J. (1975). Research on internal migration in the United States: A survey. Journal of Economic Literature, 13(2), 397-433.

Greenwood, M. J. (1985). Human migration: Theory, models, and empirical studies. Journal of Regional Science, 25(4), 521-544.

Greenwood, M. J. (1997). Internal migration in developed countries. In M. R. Rosenzweig \& O. Stark (Eds.), Handbook of population and family economics (Vol. 1B, pp. 647-720). Amsterdam: Elsevier Science Publishers.

Iredale, R. (2001). The migration of professionals: Theories and typologies. International Migration, $39(5), 7-26$.

Kley, S. (2011). Explaining the stages of migration within a life-course framework. European Sociological Review, 27(4), 469-486.

Kley, S. A., \& Mulder, C. H. (2010). Considering, planning, and realizing migration in early adulthood. The influence of life-course events and perceived opportunities on leaving the city in Germany. Journal of Housing and the Built Environment, 25(1), 73-94.

Kodrzycki, Y. K. (2001). Migration of recent college graduates: Evidence from the national longitudinal survey of youth. New England Economic Review, 2001, 13-34.

Kulu, H. (2008). Fertility and spatial mobility in the life course: Evidence from Austria. Environment and Planning A, 40(3), 632-652.

Long, J. F. (1985). Migration and the phases of population redistribution. Journal of Development Economics, 17(1-2), 29-42.

Mayer, K. U. (2004). Whose lives? How history, societies, and institutions define and shape life courses. Research in Human Development, 1(3), 161-187.

Mayer, K. U. (2009). New directions in life course research. Annual Review of Sociology, 35, 413-433.

Mincer, J. (1978). Family migration decisions. Journal of Political Economy, 86(5), 749-773.

Muhidin, S. (2002). The population of Indonesia. Amsterdam: Rozenberg Publishers.

Mulder, C. H. (1993). Migration dynamics: A life course approach. Amsterdam: Thesis Publishers.

Mulder, C. H., \& Hooimeijer, P. (1999). Residential relocations in the life course. In L. J. G. Van Wissen \& P. A. Dykstra (Eds.), Population issues: An interdisciplinary focus (pp. 159-186). New York: Plenum.

Mulder, C. H., \& Wagner, M. (1993). Migration and marriage in the life course: A method for studying synchronized events. European Journal of Population/Revue européenne de Démographie, 9(1), 55-76.

Naim, M. (1974). Voluntary migration in Indonesia. PhD Thesis, University of Singapore, Singapore.

Nivalainen, S. (2003). Who move to rural areas? Micro evidence from Finland. In ERSA 2003 Conference, Jyväskylä, Finland. http://www-sre.wu.ac.at/ersa/ersaconfs/ersa03/cdrom/papers/214. pdf. Accessed 20 May 2015.

Rahman, M. A. (1991). Self-selection and earnings: A cross section analysis of US immigrants. The Bangladesh Development Studies, 19(4), 1-26.

Rogers, A., \& Castro, L. J. (1981). Age patterns of migration: Cause-specific profiles. Research Reports, $R R-81-6,125-159$.

Rogers, A., Muhidin, S., Jordan, L., \& Lea, M. (2004). Indirect estimates of age-specific interregional migration flows in Indonesia based on the mobility propensities of infants. In Working Paper, Boulder (University of Colorado).

Rogers, A., Willekens, F., \& Raymer, J. (2001). Modeling interregional migration flows: Continuity and change. Mathematical Population Studies, 9(3-4), 231-263.

Stevens, J. B. (1980). The demand for public goods as a factor in the nonmetropolitan migration turnaround. In D. L. Brown \& J. M. Wardwell (Eds.), New directions in urban-rural migration: The population turnaround in rural America (pp. 115-135). New York: Academic Press.

Stockdale, A. (2002). Towards a typology of out-migration from peripheral areas: A Scottish case study. International Journal of Population Geography, 8(5), 345-364.

Stockdale, A., \& Catney, G. (2014). A life course perspective on urban-rural migration: The importance of the local context. Population, Space and Place, 20(1), 83-98. 
Strauss, J., Witoelar, F., \& Sikoki, B. (2016). The fifth wave of the Indonesia family life survey: Overview and field report: Volume 1. Santa Monica, CA: RAND Corporation. http://www.rand.org/pubs/ working_papers/WR1143z1.html. Accessed 26 September 2016.

Wajdi, N. (2010). Migrasi Antarpulau di Indonesia: Analisis Model Skedul Migrasi dan Model Gravitasi Hybrida [Inter-islands Migration in Indonesia: Model Migration Schedules and Hybrid Gravity Model Analysis]. Master Thesis, University of Indonesia, Indonesia.

Wajdi, N., Van Wissen, L. J., \& Mulder, C. H. (2015). Interregional migration flows in Indonesia. Sojourn: Journal of Social Issues in Southeast Asia, 30(2), 371-422.

Warnes, A. M. (1992). Migration and the life course. In T. Champion \& T. Fielding (Eds.), Migration processes and patterns: Research progress and prospects (Vol. 1, pp. 175-187). London: Belhaven Press.

Whisler, R. L., Waldorf, B. S., Mulligan, G. F., \& Plane, D. A. (2008). Quality of life and the migration of the college-educated: A life-course approach. Growth and Change, 39(1), 58-94.

World Bank. (2012). Indonesia-The rise of metropolitan regions: Towards inclusive and sustainable regional development. Washington, DC: World Bank. 